\title{
Biological Soil Disinfestation (BSD), a new control method for potato brown rot, caused by Ralstonia solanacearum race 3 biovar 2
}

\author{
Nevein A. S. Messiha · Anne D. van Diepeningen · Marcel Wenneker • \\ Alexander R. van Beuningen · Jaap D. Janse · Trudie G. C. Coenen • \\ Aad J. Termorshuizen · Ariena H. C. van Bruggen · Wim J. Blok
}

Received: 15 September 2006/ Accepted: 29 January 2007/ Published online: 27 February 2007

(C) KNPV 2007

\begin{abstract}
The potential of Biological Soil Disinfestation (BSD) to control potato brown rot, caused by Ralstonia solanacearum race 3 biovar 2, was investigated. BSD involves the induction of anaerobic soil conditions by increasing microbial respiration through incorporation of fresh organic amendments (here: grass or potato haulms) and by reducing re-supply of oxygen by covering with airtight plastic sheets. Control treatments were left without cover and amendment, or amended without covering or covered only without amendment. The effect of BSD on survival of $R$. solan-
\end{abstract}

N. A. S. Messiha - A. D. van Diepeningen .

T. G. C. Coenen · A. J. Termorshuizen ·

A. H. C. van Bruggen · W. J. Blok ( $₫)$

Biological Farming Systems Group, Wageningen

University, Marijkeweg 22, 6709 PG Wageningen,

The Netherlands

e-mail: wim.blok@wur.nl

N. A. S. Messiha - M. Wenneker .

A. R. van Beuningen · J. D. Janse

Department of Bacteriology, Plant Protection Service,

Geertjesweg 15, 6706 EA Wageningen,

The Netherlands

N. A. S. Messiha

Potato Brown Rot Project (PBRP), 3 El-Amira Fatma Ismail Street, Dokki, Cairo, Egypt

M. Wenneker

Applied Plant Research, Wageningen UR, P.O. Box 200, 6670 AE Zetten, The Netherlands acearum was tested at three different scales: in 1-1 glass mesocosms under laboratory conditions, in 1.2-m-diam microplots positioned in an outdoor quarantine field, and in a naturally infested commercial field. Within a few days, anaerobic conditions developed in the BSD-treated soils. In the mesocosm and microplot experiment, anaerobic conditions persisted till the end of the 4week experimental period. In the field experiment, the period of anaerobiosis was shorter due to birds damaging the plastic cover. In all three experiments, BSD reduced soil populations of R. solanacearum significantly by $92.5 \%$ to $>99.9 \%$ compared to the non-amended and uncovered control treatments. In the field experiment, BSD also resulted in a significant reduction of $R$. solanacearum survival in potato tubers buried at 15 or $35 \mathrm{~cm}$ and in the rapid decomposition of superficially buried potatoes remaining after harvesting, thus destroying an important inoculum reservoir of $R$. solanacearum. The treatments with grass amendment only or covering with only plastic did not result in anaerobic conditions and did not decrease $R$. solanacearum populations during the experimental period. PCR-DGGE analyses of 16S-rDNA from soil samples of the various treatments in the mesocosm and microplot experiments revealed that BSD hardly affected bacterial diversity but did result in clear shifts in the composition of the bacterial community. The possible implications of 
these shifts are discussed. It is concluded that BSD has the potential to strongly decrease soil infestation levels of $R$. solanacearum and to become an important element in a sustainable and effective management strategy for potato brown rot, especially in areas where the disease is endemic.

Keywords Anaerobiosis - Soilborne pathogens · Non-chemical control · Fresh organic matter

\section{Introduction}

Potato brown rot caused by the bacterium Ralstonia solanacearum race 3 biovar 2 is a quarantine disease with zero tolerance in the Netherlands. The pathogen is soilborne and can persist in soil for a long time in infected host plant debris or by colonizing potato volunteer plants, alternative hosts or even non-host plants (Akiew \& Trevorrow, 1994; Graham, Jones, \& Lloyd, 1979; Granada \& Sequeira, 1983). In the absence of potato, the pathogen was found to survive up to 3 years in soil (Graham et al., 1979). Cultural control through crop rotation is commonly used but requires long periods without host crops, and must be combined with strict control of volunteer host plants. Two seasons of non-host crops reduced wilt from $81 \%$ to only $22-49 \%$ (Lemaga, Kanzikwera, Kakuhenzire, Hakiza, \& Maniz, 2001). Completely resistant potato cultivars are not yet commercially available (Zimnoch-Guzowska, Lebecka, \& Flis, 2005). Most cultivars that seem to show (partial) resistance appear to be tolerant. The level of tolerance that is expressed can be negatively affected by environmental conditions (Boshou, 2004), such as high temperature (French \& De Lindo, 1982), low light intensity and short photoperiods (Sequeira \& Rowe, 1969). Chemical control of potato brown rot with currently available crop protectants is not effective (Hartman \& Elphinstone, 1994; Lopez \& Biosca, 2004). Development of more effective chemical control methods is not encouraged due to the general awareness about negative impacts of synthetic crop protectants on human health and the environment; this has led to the phasing out of an increasing number of crop protectants. The latter is exemplified by the widely used and very effective soil fumigant methyl bromide (MB), which has been prohibited for agricultural use in developed countries since 2005 and will be prohibited in developing countries by 2015 (Duniway, 2002). Some countries, for example the Netherlands, started to restrict its use even earlier because of its toxicity (Braun \& Supkoff, 1994).

In the Netherlands, potato brown rot is currently effectively managed by enforcing the statutory measures of the Brown Rot Control Directive 98/57/EC, which requires not growing potato or alternative host crops for a minimum period of four years in infested fields and applying strict control of volunteer plants in this period. However, a four-year period without host crops of $R$. solanacearum is a severe restriction for specialized potato farmers and costly and timeconsuming for inspection services. Therefore, there is a clear need to develop alternative practical, safe and effective management strategies that can shorten the time that no host plants can be grown. Candidate methods include solarization (Gamliel \& Stapleton, 1993; Katan, 1981), organic amendments (Conn, Tenuta, \& Lazarovits, 2005; Gorissen, van Overbeek, \& van Elsas, 2004; Lazarovits, Tenuta, \& Conn, 2001) and Biological Soil Disinfestation (BSD). BSD is a new method, first described by Blok, Lamers, Termorshuizen, and Bollen (2000). With BSD, anaerobic soil conditions are induced by increasing microbial respiration through incorporation of fresh organic amendments (e.g. grass) and by reducing re-supply of oxygen by covering with airtight plastic sheets (Blok et al., 2000). Under these conditions the survival of a number of persistent soilborne pathogenic fungi and nematodes, including Fusarium oxysporum, Meloidogyne spp., Rhizoctonia solani, $R$. tuliparum, Sclerotinia sclerotiorum and Verticillium dahliae, was strongly reduced or completely eradicated in repeated field experiments over the last ten years (Blok et al., 2000; Blok et al., unpublished; Goud, Termorshuizen, Blok, \& van Bruggen, 2004; Lamers, Wanten, \& Blok, 2004). The effect of BSD on survival of $R$. solanacearum has not yet been tested. However, data obtained by 
Termorshuizen et al. (2003) indicated that BSD could also be effective against $R$. solanacearum. They studied the effect of anaerobic mesophilic digestion of vegetable, fruit and garden waste on the survival of a number of pathogens including $R$. solanacearum and found that $R$. solanacearum was readily inactivated under these conditions.

The aim of the present study was to investigate the effect of BSD on survival of $R$. solanacearum in order to develop a practical, effective and sustainable management strategy for this important quarantine pathogen. Since many soil disinfestation methods have also a more or less drastic effect on non-target soil organisms, an attempt was made to also evaluate the effect of BSD on the soil bacterial community. Because $R$. solanacearum is a quarantine pathogen there are limitations to the experiments that can be carried out. The effect of BSD on the survival of $R$. solanacearum was first tested in a field experiment. This was done in 1999 when potato brown rot had been recently detected in the Netherlands and a few heavily infested fields were available. In later years, the disease was under control and infested fields that could be used for further field experiments were no longer available. To further explore the potential of BSD two additional experiments were carried out in which field application of BSD was simulated, first using glass mesocosms under laboratory conditions and then using microplots situated in an outdoor quarantine area.

\section{Materials and methods}

\section{General set-up}

A field experiment was performed in a commercial field of starch potato at Dalerveen (province of Drenthe, the Netherlands) that had a high natural infestation with $R$. solanacearum. The effect of BSD was further studied using glass mesocosms under laboratory conditions and then in microplots consisting of concrete rings (1.2-m diam) filled with soil, which were positioned in the outdoor quarantine field of the Plant Protection Service and had a cage of metal wires around and above it. Anaerobic soil conditions were induced by increasing microbial respiration through incorporation of fresh organic amendments (grass or potato haulms) and by reducing re-supply of oxygen by covering with airtight plastic sheets (Blok et al., 2000). The soil was covered with airtight plastic tarps (Hermetix, a three-layered coextruded plastic ensilage film, $0.135 \mathrm{~mm}$ thick, produced by Klerks Plastic Industry, Noordwijkerhout, the Netherlands). Hermetix has a green and a white side, and the oxygen diffusion rate is $1400 \mathrm{ml} \mathrm{O}_{2} \mathrm{~m}^{-2} 24 \mathrm{~h}^{-1}$. The tarp was applied with the green side up.

Inoculation and isolation of the pathogen

In this study a mixture of equal amounts of three virulent $R$. solanacearum race 3 biovar 2 strains (PD5239, PD5240, and PD5241; culture collection Plant Protection Service, Wageningen, the Netherlands) was used as inoculum. These strains were originally isolated from infected potato tubers from Egypt and all were found able to reduce nitrate. Nitrate reduction was tested following the protocol of Fahy and Persley (1983).

The cultures used for soil inoculation were grown for $48 \mathrm{~h}$ on nutrient agar (NA; Difco, Detroit, MI, USA) plates at $28^{\circ} \mathrm{C}$. The inoculum was suspended in $0.01 \mathrm{M}$ phosphate buffer (PB: $\mathrm{Na}_{2} \mathrm{HPO}_{4} \cdot 12 \mathrm{H}_{2} \mathrm{O}, \quad 2.7 \mathrm{~g} ; \quad \mathrm{NaH}_{2} \mathrm{PO}_{4} \cdot 2 \mathrm{H}_{2} \mathrm{O}$, $0.4 \mathrm{~g} ; 11$ distilled water; $\mathrm{pH}$ 7.2). The bacterial density was adjusted to $0.5 \times 10^{9} \mathrm{CFU} \mathrm{ml}^{-1}$ using a spectrophotometer $\quad\left(\mathrm{OD}_{600}=0.3\right.$ equals $0.5 \times 10^{9} \mathrm{CFU} \mathrm{ml}^{-1}$ ). For isolation of the pathogen, $10 \mathrm{~g}$ of soil was suspended in $90 \mathrm{ml}$ of sterile $0.05 \mathrm{M} \mathrm{PB}\left(\mathrm{Na}_{2} \mathrm{HPO}_{4} \cdot 12 \mathrm{H}_{2} \mathrm{O}, 4.26 \mathrm{~g} ; \mathrm{KH}_{2} \mathrm{PO}_{4}\right.$, $2.72 \mathrm{~g} ; 11$ distilled water; $\mathrm{pH}$ 7.2). After shaking at $100 \mathrm{rpm}$ for $2 \mathrm{~h}$ at $20^{\circ} \mathrm{C}, 10$-fold serial dilutions were made and $100 \mu \mathrm{l}$ aliquots were plated in triplicate onto modified SMSA (Selective Medium South Africa) agar plates (Anon., 1998) and incubated at $28^{\circ} \mathrm{C}$ for 5-7 days. Per sample, the identity of three colonies with a morphology typical for $R$. solanacearum (irregular shape, diffuse white or purple centres and luxuriant slime) was checked using Immunofluorescence Antibody Staining (IFAS; Janse, 1988). Plate counts were expressed as colony-forming units (CFU) per g dry soil. 
Physical, chemical and biological soil characteristics

The soil used for the mesocosm and microplot experiments was sandy (1.4\% clay, $5.9 \%$ silt and $92.7 \%$ sand) with $\mathrm{pH}-\mathrm{CaCl}_{2} 7.3,1.4 \%$ organic matter, $7.2 \mathrm{~g} \mathrm{C}, 0.8 \mathrm{~g} \mathrm{~N}$ and $36.0 \mathrm{mg} \mathrm{NO}_{3}^{-}-\mathrm{N}$, all $\mathrm{kg} \mathrm{soil}{ }^{-1}$. The area where the field experiment was located had a mixed sand-peat soil that was not analyzed in detail.

For DNA analyses, 1-2 g samples of sandy soil were collected and stored at $-20^{\circ} \mathrm{C}$ for DNA extraction within 6 months. Soil bacterial diversity was studied using polymerase chain reactiondenaturing gradient gel electrophoresis (PCRDGGE). For DNA extraction, PCR and DGGE analysis, the methods described by Hiddink, Termorshuizen, Raaijmakers, and van Bruggen (2005) were followed, the main steps of which are described below. Total DNA was extracted from 0.5-g soil samples using the Bio101 FastDNA ${ }^{\circledR}$ SPIN Kit for Soil according to the manufacturer's specifications (Bio101, Vista, CA, USA) except that before the final centrifugation step the DNA extract was incubated for $20 \mathrm{~min}$ at $65^{\circ} \mathrm{C}$ for better DNA elution. The DNA quality and quantity were checked on a $1.2 \%$ agarose gel stained with ethidium bromide and visualized by UV trans-illumination (Sambrook, Fritsch, \& Maniatis, 1989). The PCR used the U968 (40 bp GC clamp) and L1401 universal eubacterial primers (Heuer \& Smalla, 1997) and primers FR1 (58 bp BC-clamp) and FF390 (Vainio \& Hantula, 2000) for amplification of fungal smallsubunit (SSU) rDNA. The amount and quality of the obtained PCR products were again checked as described before. DGGE was performed using the Dcode Universal Mutation Detection System (BIO-Rad Laboratories, Hercules, CA, USA) with a vertical denaturing gradient of $45-60 \%$ (100\% denaturant is defined as $7 \mathrm{M}$ urea plus $40 \%$ formamide; the gel was topped with a $8 \%$ acrylamide stack without denaturing agents). Gels were run at $60^{\circ} \mathrm{C}$ at $100 \mathrm{~V}$ for $16 \mathrm{~h}$ and bands were visualized using the Bio-Rad Silver Stain Kit. After scanning, gels were analyzed with Phoretix 1D Advanced version 4.00 (NonLinear Dynamics Ltd., Newcastle upon Tyne, UK). The bacterial diversity in the samples was estimated in two ways: as species richness $S$, and as the Shannon-Wiener index of bacterial diversity, $H$ (Eichner, Erb, Timmis, \& Wagner-Döbler, 1999; van Diepeningen, de Vos, Korthals, \& van Bruggen, 2006).

Mesocosm experiment

Mesocosms consisted of 1-1 glass beakers of $18 \mathrm{~cm}$ height and $9 \mathrm{~cm}$ diam with one short glass tube halfway. A porous rubber tube of $10 \mathrm{~cm}$ length was placed inside the glass tube and extended into the beaker. This tube provided a space from which the soil atmosphere could be sampled by piercing the septum with a syringe needle. At the start of the experiment soil was infested with $R$. solanacearum by adding a bacterial suspension that resulted in a density of $5 \times 10^{7} \mathrm{CFU} \mathrm{g}^{-1} \mathrm{dw}$ soil. Soil for the grassamended treatments was mixed with grass leaves that were cut into pieces of $1-2 \mathrm{~cm}$ in a $0.1 \%$ ratio $(\mathrm{dw} / \mathrm{dw})$. The mesocosms were filled with soil in layers that were compacted after adding a new layer to ensure a homogeneous porosity over the whole profile. The amount of soil and water and the compaction were such that the volumetric proportion of solids, water and air was $55 \%, 25 \%$ and $20 \%$, respectively, which are values that are representative for the field experiments with BSD performed earlier. Mesocosms that were covered received a Vaseline layer on the edge to ensure an airtight seal between the mesocosm and the Hermetix plastic cover. The latter was kept in place with rubber bands and tape. The following treatments were used in this experiment: (1) non-amended and uncovered (positive control; 15 mesocosms); (2) grass-amended and covered (BSD treatment; 15 mesocosms); (3) grass-amended and uncovered (5 mesocosms) (4) non-amended and covered (5 mesocosms). The mesocosms were placed completely randomized in an incubator at $28^{\circ} \mathrm{C}$. A mesocosm filled with non-infested, non-amended soil was left uncovered and was incubated under the same conditions to serve as a negative control for the detection of $R$. solanacearum. The mesocosms that were not covered with Hermetix were covered with parafilm, which allowed air exchange but reduced evaporation. 
One milliliter soil atmosphere samples were collected from each mesocosm twice a week and oxygen and carbon dioxide concentrations were determined with a gas chromatograph (Chrompack Micro-GC 2002).

The population density of the pathogen in the soil was determined at the start of the experiment for all the mesocosms. After 17 days, five mesocosms of the positive control and five mesocosms of the BSD treatment were opened and sampled for pathogen quantification. After 31 days all remaining mesocosms were opened and samples were collected for pathogen quantification and for DNA extraction and PCR-DGGE. The latter samples were stored at $-20^{\circ} \mathrm{C}$. Soil from three BSD-treated mesocosms were aerobically incubated in loosely capped, $50 \mathrm{ml}$ centrifuge tubes at $28^{\circ} \mathrm{C}$ for an extra period of 3 weeks to study the changes in the composition of the bacterial community upon return to aerobic conditions. PCR-DGGE patterns of the following treatments (with number of samples per treatment given in brackets) were compared: non-amended, uncovered control (3), grass-amended, uncovered (1), non-amended, covered (1), BSD, harvested after 17 days (1), BSD, harvested after 31 days (2) and BSD, harvested after 31 days and stored aerobically for an additional 3 weeks (2).

\section{Microplot experiment}

This experiment was conducted in the quarantine field at the Plant Protection Service (Wageningen, the Netherlands). In this field 12 microplots were available for the experiment. The microplots consisted of concrete rings with internal diameter of $120 \mathrm{~cm}$ and height of $40 \mathrm{~cm}$. The rings were open at the bottom and buried almost completely into the soil. The following four treatments were compared: (1) non-amended and uncovered (3 microplots); (2) grass-amended and covered (BSD treatment; 3 microplots); (3) grassamended and uncovered (2 microplots); (4) nonamended and covered ( 2 microplots). The microplots were filled with sandy soil similar to the soil used for the mesocosm experiment. For the grassamended treatments, the soil was first mixed thoroughly with mown grass in a $0.1 \%$ ratio $(\mathrm{dw} /$ $\mathrm{dw})$. After filling the microplots with soil, three inoculum samples were buried in each microplot. These inoculum samples consisted of nylon bags filled with $2.5 \mathrm{~kg}$ soil from that microplot, infested with $R$. solanacearum race 3 biovar 2 to a density of $10^{6} \mathrm{CFU} \mathrm{g}^{-1} \mathrm{dw}$ soil. The remaining two microplots were filled with non-amended soil and left uncovered and received three nylon bags with soil to which non-infested PB buffer was added; these samples served as negative controls. All microplots were then irrigated to field capacity to stimulate microbial activity. Finally, the plastic covers were applied. Because of the small diameter of the microplots, oxygen supplied from the borders with untreated soil could have a relatively large effect on soil oxygen levels in the microplot and could prevent reaching anaerobiosis. To reduce this border effect, the plastic covers were buried to $50 \mathrm{~cm}$ depth to cover the outside of the concrete ring. In addition, a shallow ditch was made around the microplot that was frequently filled with water to create an oxygen barrier layer of water-saturated soil around the covered microplot. The experiment was finished by removing the plastic covers after 31 days.

The oxygen level of the soil atmosphere was measured twice a week using an oxygen analyzer (570 A; Servomex, Crowborough, East Sussex, UK.). Soil atmosphere samples were extracted with this analyzer from three gas diffusion chambers that were buried in each microplot at $15 \mathrm{~cm}$ depth. The gas diffusion chamber consisted of a piece of PVC tubing (diam $1.6 \mathrm{~cm}$, length $5 \mathrm{~cm}$, volume $10 \mathrm{ml}$ ) that was open at the bottom and closed with a butyl rubber stopper at the top. The rubber stopper was pierced by copper tubing (internal diam $1.0 \mathrm{~mm}$ ) extending about $5 \mathrm{~cm}$ above the soil surface. The copper tube was fitted at the top with a copper head closed with a rubber septum and crimp cap. The soil temperature was measured every hour using thermocouples buried at $15 \mathrm{~cm}$ depth in one microplot for each treatment, and a data logger (DL2e, Delta-T Devices Ltd, Burwell, Cambridge, United Kingdom). Pathogen population densities for each inoculum sample were determined as described earlier at the beginning and end of the experiment. Three subsamples were tested from each inoculum sample.

For PCR-DGGE analyses, soil samples were collected from four grass-amended microplots at 
the start of the experiment. At the end of the experiment, two samples were collected from BSD microplots, two samples from grassamended, uncovered microplots and two samples from non-amended, covered microplots. These samples were stored at $-20^{\circ} \mathrm{C}$ for DNA extraction at a later time.

\section{Field experiment}

This experiment was conducted in a commercial field of a mixed sand-peat soil at Dalerveen in the province of Drenthe, the Netherlands. In this field a potato crop had been grown in which, during the summer of 1999, a heavy infection of brown rot was detected. The foliage was cut using a rotary cultivator in mid-August. Three days later the crop residues were incorporated to a depth of $25 \mathrm{~cm}$ using a rototiller and six plots of $7 \times 8 \mathrm{~m}$ were laid out. The amount of incorporated potato material was about 30 tons fresh weight $\mathrm{ha}^{-1}$. In each plot, nylon bags, each containing one $R$. solanacearum-infected potato tuber, were buried, three bags at a depth of $15 \mathrm{~cm}$ and three at $35 \mathrm{~cm}$. After the soil was compacted with tractor wheels, gas diffusion chambers, as described earlier, were installed in one uncovered and one covered plot (three chambers in each plot at $15 \mathrm{~cm}$ ). Fifty soil cores were collected from $0-15 \mathrm{~cm}$ depth and mixed into one composite sample for each of the six plots. Finally, three randomly selected plots were covered with Hermetix plastic sheets, burying the edges to a depth of $10 \mathrm{~cm}$.

Oxygen and methane concentrations of the soil atmosphere were measured after 7 and 35 days from the start of the experiment. Samples were extracted using evacuated blood collection tubes and analyzed at the laboratory using a Varian $3200 \mathrm{cx}$ gas chromatograph. After 6 weeks, the plastic covers were removed, the nylon bags were retrieved and one composite soil sample was collected for $0-15 \mathrm{~cm}$ and one for $30-45 \mathrm{~cm}$ from each plot using 50 and 20 randomly collected soil cores, respectively.

The potato tubers buried were collected from plants that had grown in the experimental field and had shown typical brown rot symptoms. $R$. solanacearum infection of the tubers was confirmed by slime exudation from eyes and isolation of $R$. solanacearum from vascular tuber tissue plated onto SMSA plates (Anon., 1998). After retrieval of the nylon bags, pieces of potato vascular tissue from different positions in the tuber were suspended and shaken for $1 \mathrm{~h}$ in phosphate buffer, and then $100-\mu \mathrm{l}$ aliquots were plated onto SMSA. Soil adhering to the tuber was also plated onto SMSA to test for spread of $R$. solanacearum from the tuber or tuber residues into the surrounding soil and subsequent survival. The density of $R$. solanacearum in the soil samples collected at the start and end of the experiment was determined as described earlier. In addition, pathogencity testing, PCR and fatty acid analysis were used to confirm the identity of colonies with a morphology characteristic for R. solanacearum (Janse, 1988, 1991; Pastrik \& Maiss, 2000; Roy, 1988).

Statistical analyses

Data of $R$. solanacearum population density of the mesocosm experiment were subjected to Analysis of Variance (ANOVA) on log-transformed data $(\log (\mathrm{CFU}+1))$ followed by Tukey's mean separation test using SPSS, version 12 (SPSS Inc., Chicago, Illinois, USA). For the microplot and the field experiment the means for $R$. solanacearum population densities of the control and BSD treatment were compared with the non-parametric Mann-Whitney U test using SPSS.

The PCR-DGGE banding patterns were first analyzed by hierarchical cluster analysis of the band intensity data using the Dice coefficient and the UPGMA algorithm with the Phoretix software (Nonlinear Dynamics Ltd, Newcastle upon Tyne, UK). The banding patterns were further analyzed with Principal Component Analysis (PCA) using the PRINCOMP procedure of SAS, version 9.1 (SAS Institute Inc., Cary, NC, USA) on log-transformed band intensities and with Discriminant Analyis (DA) using the DISCRIM, CANDISC, and STEPDICS procedures of SAS. For the DA, each data set was first split into small subgroups of five variables and the most discriminating variables were then combined and subjected to the final analyses (van 
Diepeningen et al., 2006). The banding patterns compared in one PCA or DA analysis were all from the same gel. The values of the diversity indices calculated from the PCR-DGGE banding patterns for the mesocosm and microplot experiment were analyzed together using ANOVA and mean separation by a protected LSD test using PROC GLM of SAS.

\section{Results}

\section{Mesocosm experiment}

Three days after starting the experiment the oxygen percentage in the BSD mesocosms had dropped to $1.7 \pm 0.21 \%$, indicating almost complete anaerobiosis. The oxygen levels for the control and the grass-amended, uncovered treatments were $16.8 \pm 0.97 \%$ and $14.9 \pm 1.4 \%$, respectively. The non-amended, covered mesocosms had an oxygen level of $3.7 \pm 0.88 \%$, which indicates that also in these mesocosms a large part of the soil volume experienced anaerobic conditions in the first period after covering. As from one week after the start of the experiment, oxygen levels of all non-BSD treatments were similar $(>16.0 \%)$, whereas the oxygen levels in the BSD mesocosms were $<1.0 \%$.

At the start of the experiment the $R$. solanacearum population density was equal in all mesocosms: $6.50 \pm 0.30$ (mean \pm SEM of $\log$ $\left(\mathrm{CFU} \mathrm{g} \mathrm{g}^{-1} \mathrm{dw}\right.$ soil +1$\left.)\right)$. After 17 days a trend of more inactivation by BSD was found with a density of $4.49 \pm 0.01$ and $3.30 \pm 0.52$ in the control and BSD mesocosms, respectively. After 31 days, $R$. solanacearum was almost completely eradicated from the BSD mesocosms, leaving only $0.59 \pm 0.31$, while its population density was still above 3.60 in the other treatments (Table 1 ).

The species richness $(S)$ and Shannon-Wiener diversity index $(H)$ derived from the PCR-DGGE banding patterns of the $16 \mathrm{~S}$ rDNA were quite similar for the four treatments. There were not sufficient values to perform proper statistical tests and, therefore, the data were combined with similar data from the microplot experiment for comparing treatment means (Table 2). The composition of the bacterial microflora was different among the treatments as shown by cluster analysis of the banding patterns. These analyses showed that the BSD samples are clearly separated from

Table 1 Effect of the different treatments applied in the mesocosm experiment on survival of $R$. solanacearum after 17 and 31 days of incubation

\begin{tabular}{llr}
\hline Treatment & 17 days incubation $^{\mathrm{a}}$ & 31 days incubation $^{\mathrm{a}}$ \\
\hline Non-amended, uncovered (control) & $4.49 \pm 0.01 \mathrm{a}$ & $3.73 \pm 0.02 \mathrm{a}$ \\
Grass-amended, covered (BSD) & $3.30 \pm 0.52 \mathrm{a}$ & $0.59 \pm 0.31 \mathrm{~b}$ \\
Grass-amended, uncovered & & $4.07 \pm 0.15 \mathrm{a}$ \\
Non-amended, covered & & $3.60 \pm 0.05 \mathrm{a}$
\end{tabular}

${ }^{a}$ Values presented are means \pm SEM of log-transformed numbers $(\log (\mathrm{CFU}+1))$. Means with a different letter are statistically different according to Tukey's multiple range test $(P<0.05)$

Table 2 Species richness $(S)$ and Shannon-Wiener index of bacterial diversity $(H)$ calculated from PCR-DGGE banding patterns for eubacterial 16S-rDNA extracted from

\begin{tabular}{llr}
\hline Treatment & $S^{\mathrm{a}}$ & $H^{\mathrm{a}}$ \\
\hline Non-amended, uncovered (Control) & $30.5 \pm 0.5 \mathrm{a}$ & $1.43 \pm 0.01 \mathrm{a}^{1}$ \\
Grass-amended, covered (BSD) & $29.0 \pm 1.0 \mathrm{a}$ & $1.26 \pm 0.05 \mathrm{c}$ \\
Grass-amended, uncovered & $30.5 \pm 1.2 \mathrm{a}$ & $1.41 \pm 0.02 \mathrm{ab}$ \\
Non-amended, covered & $28.0 \pm 2.0 \mathrm{a}$ & $1.36 \pm 0.04 \mathrm{abc}$ \\
\hline
\end{tabular}

\footnotetext{
a Values presented are means \pm SEM

1 Values with a letter in common do not differ statistically according to the protected LSD-test $(P<0.05)$
}

differently treated soil collected at the end of the mesocosm and microplot experiments 
the other samples and that the samples from the non-BSD treatment clustered together. The BSD samples that were incubated for 3 weeks after the end of the experiment still clustered with the BSD samples collected immediately after the end of the experiment indicating that there was not a fast return to the original bacterial community composition (Fig. 1). The groupings revealed by the cluster analysis were confirmed by those of a principal component analysis (data not shown). DA identified eight bands as the most discriminative ones $(11 \%$ from the total number of detected bands). Four of these bands were found only in samples from the control treatment, two bands were found only in the BSD (including the BSD samples stored for an extra 3 weeks), one band was found in higher density in BSD soil samples compared to control samples and one band was found only in the BSD samples stored for an extra 3 weeks.

\section{Microplot experiment}

The oxygen levels of the soil atmosphere showed roughly the same trend as found in the mesocosm experiment with $>15 \%$ in the non-BSD microplots and low values in the BSD microplots. In contrast to what was found in the mesocosm experiment, the non-amended, covered treatment did not show a decrease in oxygen content in the first period after covering. For the BSD treatment, two of the three microplots had oxygen levels $<1 \%$ during the whole experimental period, and in the third microplot the level was between 1 and $3 \%$. The daily mean soil temperature of the uncovered plots during the experiment ranged from $14.9-26.4^{\circ} \mathrm{C}$, the daily maximum temperature from $16.8-32.8^{\circ} \mathrm{C}$. Covering the soil raised the daily mean and the daily maximum temperature with $0.1-4.4$ and $0.0-4.3^{\circ} \mathrm{C}$, respectively.

At the start of the experiment the population density of $R$. solanacearum was similar for all microplots: $4.99 \pm 0.04$ (mean \pm SEM of $\log$ $\left(\mathrm{CFU} \mathrm{g}{ }^{-1} \mathrm{dw}\right.$ soil +1$\left.)\right)$. At the end of the experiment (after 31 days) population density was $2.69 \pm 0.14$ for the control, $3.00 \pm 0.19$ for the grass-amended, uncovered treatment and $3.18 \pm 0.13$ for the non-amended, covered treatment indicating that grass amendment alone or covering alone does not result in control of $R$. solanacearum. The BSD treatment resulted in a mean density of $1.02 \pm 0.60$, which is significantly lower than the mean of the control treatment $(P=0.050$; Mann-Whitney $U$ test $)$.
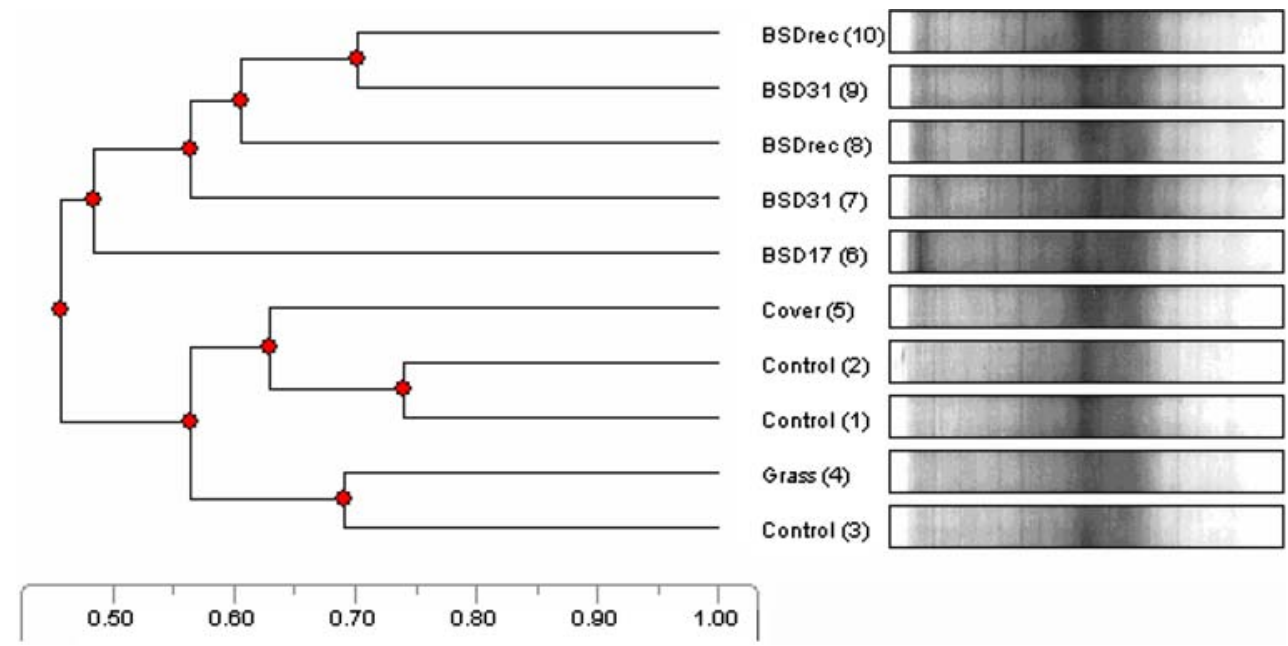

Fig. 1 UPGMA dendrograms based on Dice coefficient matrices for PCR-DGGE banding patterns of 16S-rDNA for samples of the mesocosm experiment. The meaning of the codes is as follows: Control-non-amended, uncovered; Grass-grass-amended, uncovered; Cover-nonamended, covered; BSD—grass-amended, covered. The additional codes for the BSD samples indicate the incubation period (17 or 31 days) or samples that were incubated for an additional 3-week period after the end of the experiment (rec). The scale on the $X$-axis depicts similarity 
The pathogen survival in the BSD microplots showed, however, a relatively high variation. The $\log \left(\mathrm{CFU} \mathrm{g} \mathrm{g}^{-1} \mathrm{dw}\right.$ soil +1$)$-values for the individual inoculum samples were as follows: microplot $1-0.00,0.00,0.00$; microplot 2-0.00, 0.00, 2.96; microplot $3-0.85,1.99,3.40$. As mentioned above, microplot 3 showed higher oxygen levels than microplots 1 and 2, which probably explains the higher survival of the pathogen in this microplot. $R$. solanacearum was not detected in any of the non-infested samples.

PCR-DGGE banding patterns of the BSD samples were clearly different from the nonBSD samples as revealed by cluster analysis of the data (Fig. 2). Strikingly, the grass-amended, uncovered samples were more similar to the nonamended, covered samples than to the grassamended samples collected at the start of the experiment indicating that the effect of incubation time on composition of the bacterial microflora was stronger than that of grass amendment. PCA of the DGGE data confirmed the clear separation of soil samples as revealed by the cluster analysis (data of PCA not shown). DA revealed nine bands as the most discriminative ones $(11 \%$ from the total number of detected bands). Five bands were found only in the BSD soil samples, two bands were much less intense in the BSD samples as compared to the samples from all other treatments, one band was found only in the control treatment and one band was found only in the grass-amended, uncovered treatment and in the non-amended, covered treatment.

\section{Field experiment}

The field could be visited only a few times during the experiment. During the first visit, 7 days after the start, the plastic cover was still almost completely intact. However, after 2-3 weeks birds started to make holes in the plastic tarps and after 5 weeks the tarps were severely damaged. The soil atmosphere samples collected after 7 days from the BSD plot contained very low levels of oxygen $(0.03 \pm 0.03 \mathrm{vol} \%$; mean $\pm \mathrm{SEM})$ compared to the control plots $(15.28 \pm 1.63 \mathrm{vol} \%)$ and traces of methane $(0.13 \pm 0.04 \mathrm{vol} \%)$, indicating anaerobic, reducing conditions in most of the soil volume. After 35 days, however, soil oxygen levels were similar for the control and the BSD plot $(9.44 \pm 2.48$ and $13.47 \pm 1.49 \mathrm{vol} \%$, respectively) and methane was no longer present in the BSD plot.

After removal of the plastic cover from the BSD plots, the soil surface was completely free of
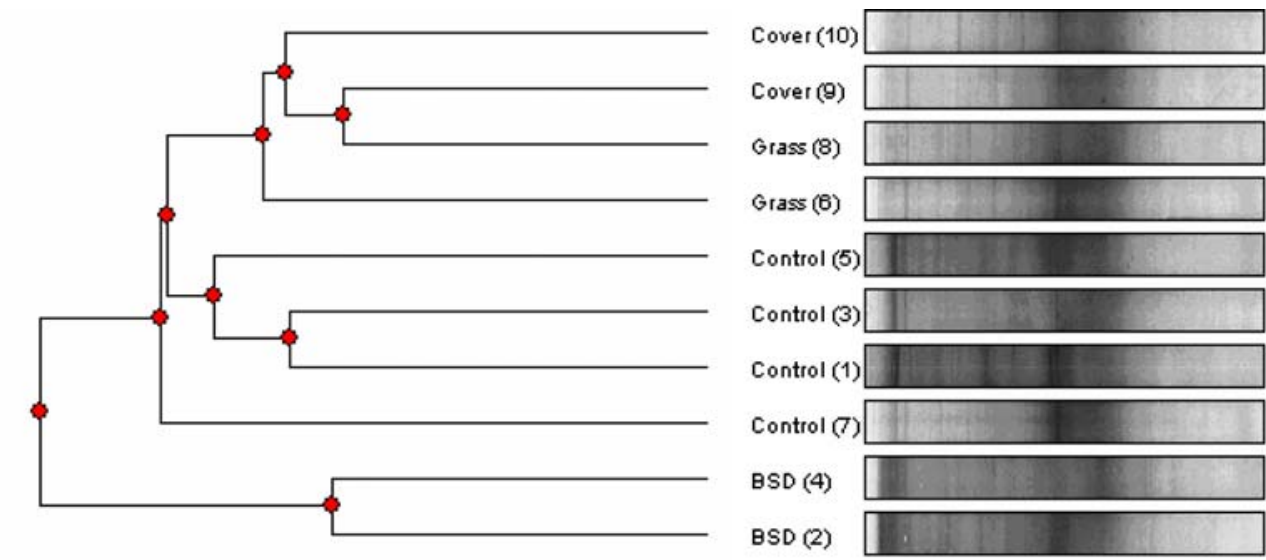

$$
\begin{array}{|c|c|c|c|c|c|c|}
\hline 0.40 & 0.50 & 0.60 & 0.70 & 0.80 & 0.90 & 1.00 \\
\hline
\end{array}
$$

Fig. 2 UPGMA dendrograms based on Dice coefficient matrices for PCR-DGGE banding patterns of 16S-rDNA for samples of the microplot experiment. The meaning of the codes is as follows: Control-grass-amended plots sampled at the start of the experiment (before covering of plots); Grass-grass-amended, uncovered, sampled at end of experiment; Cover-non-amended, covered, sampled at end of experiment; BSD-grass-amended, covered, sampled at end of experiment. The scale on the $X$-axis depicts similarity 
Table 3 Soil population density of $R$. solanacearum $(\log (\mathrm{CFU}+1))$ at the end of the field experiment

\begin{tabular}{llllll}
\hline Treatment & $0-15 \mathrm{~cm}$ & & $30-45 \mathrm{~cm}$ & \\
\cline { 2 - 3 } \cline { 5 - 6 } & Mean & $P^{\mathrm{a}}$ & & Mean & $P^{\mathrm{a}}$ \\
\hline Control & 4.55 & 0.025 & & 3.83 & 0.066 \\
BSD & 3.24 & & & 1.76 & \\
\hline
\end{tabular}

a $P$-value of the non-parametric Mann-Whitney $U$ test comparing population densities of the BSD treatment and the control treatment for each depth separately

weeds and no potato tubers were present on the surface. On the control plots numerous weeds and firm potato tubers were present. Apparently, the BSD treatment resulted in fast decomposition of the potato tubers. Thirty potato tubers were collected from the surface of the untreated plots and tested for presence of $R$. solanacearum. Thirty percent of these tubers were infected by $R$. solanacearum. Ralstonia solanacearum was detected in $55 \%$ of infected tubers that had been buried in the control plots, but was not detected in any of the tubers retrieved from BSD plots, from either 15 or $35 \mathrm{~cm}$ depth. In soil adhering to potato tubers buried on purpose, $R$. solanacearum was detected in $75 \%$ of samples collected from the control plots, while in only $5 \%$ of samples collected from BSD plots $(P=0.001)$. The infestation of the soil with $R$. solanacearum at the beginning of the experiment was found to be very similar for the six plots with a population density of $5.06 \pm 0.09\left(\log \left(\mathrm{CFU} \mathrm{g}{ }^{-1} \mathrm{dw}\right.\right.$ soil +1$\left.)\right)$. At the end of the experiment, after 6 weeks, the density of $R$. solanacearum in the BSD plots was significantly lower than that in the control plots for both the $0-15 \mathrm{~cm}$ and the $30-45 \mathrm{~cm}$ soil layer (Table 3), with reduction percentages of $92.5 \%$ and $96.7 \%$ for the $0-15 \mathrm{~cm}$ and the $30-45 \mathrm{~cm}$ soil layers, respectively.

\section{Discussion}

In this study, BSD, the combination of incorporation of easily decomposable organic matter and application of an airtight soil cover, was found to strongly reduce soil population densities of $R$. solanacearum, both under controlled laboratory conditions and under (semi-)field conditions.
Incorporation of easily decomposable organic matter, grass or potato haulms, alone or covering the soil with airtight plastic without incorporation of organic amendment did not result in reduction of $R$. solanacearum soil populations.

The microplot experiment showed, for the nine inoculum samples buried in the BSD microplots, complete eradication of the pathogen in five samples, significant reduction in two samples and no reduction in the remaining two samples. This large variation in pathogen inactivation was not found for the glass mesocosms, for which anaerobic conditions could easily be obtained and maintained, and also not for the field plots. It can most probably be explained by local oxygen leakage into the microplots locally leading to prevention or nullification of the anaerobic conditions and survival of the pathogen. Although the oxygen measurements that were performed at three places in each microplot did not indicate the presence of leakages, it cannot be excluded that outside the three measurement points oxygen levels stayed higher, preventing pathogen-inactivating soil conditions. Oxygen leakage will occur more easily in the microplots than in field plots due to the larger border length relative to the plot's surface area.

In the field experiment anaerobic conditions were not maintained for a long period due to birds damaging the plastic tarp. Nevertheless, pathogen populations were reduced significantly by more than $95 \%$. If this bird damage can be prevented, and farmers have various effective methods available for this, anaerobic conditions can be maintained for a longer period resulting in an even stronger decline of $R$. solanacearum populations (Termorshuizen et al., 2003). Especially relevant is the observation that after the BSD treatment potato tubers were completely decomposed and weed growth was absent. Potato tubers are a major reservoir of $R$. solanacearum where it normally can survive better than in soil (Graham et al., 1979). Also various weed species such as Portulaca oleracea, Rumex dentatus and Solanum nigrum, have been found to be important reservoirs for the pathogen (Elphinstone, Stanford, \& Stead, 1998; Farag, Eweda, Mostafa, \& Balabel, 2004). In this study we did not determine if weeds were really destroyed or 
showed only delayed emergence in the BSD plots. However, from other BSD studies we obtained strong indications that weed populations are indeed reduced. Destruction of these 'hiding' places for the pathogen by BSD will greatly contribute to a decrease of soil infestation levels.

The mechanism of inactivation of $R$. solanacearum was not studied in detail in this work. Most probably, toxic compounds produced during fermentation of the fresh organic matter under the anaerobic soil conditions played a major role in the decline of $R$. solanacearum populations. It has been well documented that a vast array of potentially toxic compounds, including alcohols, aldehydes and organic acids, is produced when organic matter is decomposed under anaerobic soil conditions (Ponnamperuma, 1972; Strandberg, 1987). In earlier BSD experiments we also found a temporary, strong build-up of fermentation products (Blok et al., unpublished). In addition to the toxic products produced during organic matter decomposition under anaerobic conditions, biocontrol by facultative anaerobic and strictly anaerobic bacteria such as Bacillus and Clostridium spp., respectively, may have contributed to pathogen inactivation (Cook \& Baker, 1983). The small increase in soil temperature induced by the plastic cannot explain the BSD effect found in this study as the plots with only plastic covering without incorporation of fresh organic matter, which experienced the same temperature as the BSD plots, did not show a decline in $R$. solanacearum populations. This does not exclude, however, that in other situations increased soil temperatures can contribute to pathogen inactivation. If solar radiation levels are higher, such as in Mediterranean and tropical countries, the soil temperatures can reach sublethal temperatures that will make soilborne pathogens more vulnerable to all kinds of stress factors including toxic fermentation products (Katan, 1981).

The results of this study clearly show the potential of BSD to strongly reduce the level of soil infestation by $R$. solanacearum. The levels of reduction are similar to those obtained using chemical soil disinfestations against other soilborne pathogens and pests. For the soils used in this study it was found that in bioassays under greenhouse conditions a $95 \%$ reduction in $R$. solanacearum soil infestation ( $\mathrm{cfu} \mathrm{g}^{-1}$ dry soil) resulted in $32.5 \%$ reduction in disease severity, expressed as area under the disease progress curve (AUDPC) (Messiha, 2006). If BSD becomes part of the management strategy currently used in many European countries following the Brown Rot Control Directive 98/57/EC that aims at eradication of potato brown rot, the period for which statutory measures are needed can probably be reduced considerably. Application of BSD is rather expensive because of the costs of the plastic tarp, however, if statutory measures can be lifted earlier, application of BSD will be economically attractive. However, in countries where potato brown rot is endemic, application of BSD will often be economically feasible and attractive as the losses due to potato brown rot can be high. The method might be further optimized, possibly resulting in lower costs, by using different types of plastic tarp (Lamers et al., 2004). For example, transparent, thin but oxygen-tight barrier films can be used that increase soil temperature more than the standard plastic thus combining soil solarization and BSD. The advantage of using thinner tarps would also be lower environmental costs because lower amounts of plastics are used. Environmental costs are further restricted by setting up a collection and recycling scheme for the tarps.

The results of the PCR-DGGE analyses revealed that although BSD hardly affected bacterial diversity it induced clear changes in the composition of the soil bacterial community. The observation that a 3-week aerobic incubation period following BSD did not result in a return to the pre-BSD community patterns indicates that the BSD-induced changes are relatively persistent. The effect of the changes in bacterial community composition on soil functioning cannot be deduced from our data and needs further research. Both possible negative and positive effects can be envisaged. If the altered microbial composition results in a lower natural suppressiveness of the soil against potato brown rot, this will result in increased rates of re-infestation by the pathogen, which will partially or wholly nullify the initial decline in soil populations brought about by BSD. Such effects have been 
reported for soil flooding and for soil fumigation (Kreutzer, 1965; Stover, 1979). However, we have obtained indications that for BSD, in contrast to soil flooding and chemical disinfestation, the risk of a significant decrease in disease suppressiveness of the soil is limited (Blok et al., 2000; Goud et al., 2004). In a study in which we tested disease suppressiveness against Fusarium oxysporum f.sp. asparagi immediately after BSD, thus at the most vulnerable stage, we found similar suppressiveness levels for the BSD and the untreated soil (Blok et al., 2000). A possible explanation for this result is that, unlike broad spectrum soil fumigants, BSD does not create a temporary biological vacuum but a gradual shift from an aerobesdominated microbial community to an anaerobesdominated microbial community and vice-versa upon return to aerobic conditions. A possible positive effect of the changes in microbial composition brought about by BSD is that this disturbance could offer a possibility for introduced biocontrol organisms to establish in the soil, something very hard to achieve in an undisturbed soil.

We conclude that the data presented clearly show the potential of BSD to strongly decrease soil infestation levels of $R$. solanacearum and to become an important element in a sustainable, practical and effective management strategy for potato brown rot.

Acknowledgements This project was funded by the EU through the EU-Egypt Potato Brown Rot Project Phase II (SEM03/220/51A/EGY1B/1999/0192) and by the Technology Foundation STW, applied science division of NWO and the technology programme of the Ministry of Economic Affairs. We are grateful to H. Halm and O. de Vos of the Biological Farming Systems Group of Wageningen University for skillful technical assistance. $\mathrm{We}$ are thankful to the members of Bacteriology Department of the Plant Protection Service, especially B. Briaire, G. Willemsen, J. G. B. Voogd, J. L. J. van de Bilt, N. N. A. Tjou-Tam-Sin, N. M. Landman and P. van de Werde, for technical assistance and valuable advice.

\section{References}

Akiew, E., \& Trevorrow, P. R. (1994). Management of bacterial wilt of tobacco. In A. C. Hayward \& G. L. Hartman (Eds.), Bacterial wilt: The disease and its causative agent, Pseudomonas solanacearum (pp. 179198). Wallingford: CAB International.
Anon. (1998). Interim testing scheme for the diagnosis, detection and identification of Ralstonia solanacearum (Smith) Yabuuchi et al. in potatoes. Annex II to the Council Directive 98/57/EC of 20 July 1998 on the control of Ralstonia solanacearum (Smith) Yabuuchi et al. Publication 97/647/EC, Official Journal European Communities No. L 235, 8-39.

Blok, W. J., Lamers, J. G., Termorshuizen, A. J., \& Bollen, G. J. (2000). Control of soilborne plant pathogens by incorporating fresh organic amendments followed by tarping. Phytopathology, 90, 253-259.

Boshou, L. (2004). A broad review and prospective on breeding for resistance to bacterial wilt. In C. Allen, P. Prior, \& A. C. Hayward (Eds.), Bacterial wilt disease and the Ralstonia solanacearum species complex (pp. 225-238). St. Paul, Minnesota, USA: The American Phytopathological Society.

Braun, A. L., \& Supkoff, D. M. (1994). Options to methyl bromide for the control of soil-borne diseases and pests in California with reference to the Netherlands. California Environmental Protection Agency, Department of Pesticide Regulation, Pest Management and Analysis Division, Publ. No. 94-02.

Conn, K. L., Tenuta, M., \& Lazarovits, G. (2005). Liquid swine manure can kill Verticillium dahliae microsclerotia in soil by volatile fatty acid, nitrous acid, and ammonia toxicity. Phytopathology, 95, 28-35.

Cook, R. J., \& Baker, K. F. (1983). The nature and practice of biological control of plant pathogens. St. Paul, MN, USA: The American Phytopathological Society.

Duniway, J. M. (2002). Status of chemical alternatives to methyl bromide for pre-plant fumigation of soil. Phytopathology, 92, 1337-1343.

Eichner, C. A., Erb, R. W., Timmis, K. N., \& WagnerDöbler, I. (1999). Thermal gradient gel electrophoresis analysis of bioprotection from pollutant shocks in the activated sludge microbial community. Applied and Environmental Microbiology, 65, 102-109.

Elphinstone, J. G., Stanford, H. M., \& Stead, D. E. (1998). Detection of Ralstonia solanacearum in potato tubers, Solanum dulcamara, and associated irrigation water. In P. Prior, C. Allen, \& J. G. Elphinstone (Eds.), Bacterial Wilt Disease: Molecular and Ecological Aspects. Reports of the second international bacterial wilt symposium, 22-27 June 1997, Guadeloupe (pp. 133-139). Berlin, Germany: Springer.

Fahy, P. C., \& Persley, G. J. (1983). Plant bacterial diseases, a diagnostic guide. Sydney, Australia: Academic Press.

Farag, N. S., Eweda, W. E., Mostafa, M. I., \& Balabel, N. M. (2004). Preliminary observations on the bacteriology and pathology of Ralstonia solanacearum. Egyptian Journal of Agricultural Research, 82, 1519-1523.

French, E. R., \& De Lindo, L. (1982). Resistance to Pseudomonas solanacearum in potato: specificity and temperature sensitivity. Phytopathology, 72, 14081412 .

Gamliel, A., \& Stapleton, J. J. (1993). Characterization of antifungal volatile compounds evolved from solarized soil amended with cabbage residues. Phytopathology, 83, 899-905. 
Gorissen, A., van Overbeek, L. S., \& van Elsas, J. D. (2004). Pig slurry reduces the survival of Ralstonia solanacearum biovar 2 in soil. Canadian Journal of Microbiology, 50, 587-593.

Goud, J. C., Termorshuizen, A. J., Blok, W. J., \& van Bruggen, A. H. C. (2004). Long-term effect of biological soil disinfestation on Verticillium wilt. Plant Disease, 88, 688-694.

Graham, J., Jones, D. A., \& Lloyd, A. B. (1979). Survival of Pseudomonas solanacearum race 3 in plant debris and in latently infected potato tubers. Phytopathology, 69, 1100-1103.

Granada, G. A., \& Sequeira, L. (1983). Survival of Pseudomons solanacearum in soil, rhizosphere and plant roots. Canadian Journal of Microbiology, 29, 433-440.

Hartman, G. L., \& Elphinstone, J. G. (1994). Advances in the control of Pseudomonas solanacearum Race 1 in major food crops. In A. C. Hayward \& G. L. Hartman (Eds.), Bacterial wilt: The disease and its cauative agent, Pseudomonas solanacearum (pp. 157-177). Wallingford: CABI International.

Heuer, H., \& Smalla, K. (1997). Application of denaturing gradient gel electrophoresis for studying soil microbial communities. In J. D. van Elzas, J. T. Trevors, \& E. M. H. Wellington (Eds.), Modern Soil Microbiology (pp. 353-373). New York, USA: Marcel Dekker Inc.

Hiddink, G. A., Termorshuizen, A. J., Raaijmakers, J. M., \& van Bruggen, A. H. C. (2005). Effect of mixed and single crops on disease suppressiveness of soils. Phytopathology, 95, 1325-1332.

Janse, J. D. (1988). A detection method for Pseudomonas solanacearum in symptomless potato tubers and some data on its sensitivity and specificity. Bulletin $O E P P /$ EPPO Bulletin, 18, 343-351.

Janse, J. D. (1991). Infra- and intraspecific classification of Pseudomonas solanacearum strains using whole cell fatty acid analysis. Systematic and Applied Microbiology, 14, 335-345.

Katan, J. (1981). Solar heating (solarization) of soil for control of soilborne pests. Annual Review of Phytopathology, 19, 211-236.

Kreutzer, W. A. (1965). The reinfestation of treated soil. In K. F. Baker \& W. C. Snyder (Eds.), Ecology of soilborne plant pathogens (pp. 495-507). Berkeley, CA, USA: University of California Press.

Lamers, J. G., Wanten, P., \& Blok, W. J. (2004). Biological soil disinfestation: a safe and effective approach for controlling soilborne pests and diseases. Agroindustria, 3, 289-291.

Lazarovits, G., Tenuta, M., \& Conn, K. L. (2001). Organic amendments as a disease control strategy for soilborne disease of high-value agricultural crops. Australasian Plant Pathology, 30, 111-117.

Lemaga, B., Kanzikwera, R., Kakuhenzire, R., Hakiza, J. J., \& Maniz, G. (2001). The effect of crop rotation on bacterial wilt incidence and potato tuber yield. African Crop Science Journal, 9, 257-266.

Lopez, M. M., \& Biosca, E. G. (2004). Potato bacterial wilt management: New prospects for an old problem. In C. Allen, P. Prior, \& A. C. Hayward (Eds.), Bacterial wilt disease and the Ralstonia species complex (pp. 205224). St. Paul, Minnesota, USA: APS Press.

Messiha, N. A. S. (2006). Bacterial wilt of potato (Ralstonia solanacearum race 3 , biovar2): Disease management, pathogen survival and possible eradication. $\mathrm{PhD}$ thesis Wageningen University, The Netherlands.

Pastrik, K. H., \& Maiss, E. (2000). Detection of Ralstonia solanacearum in potato tubers by polymerase chain reaction. Journal of Phytopathology, 148, 619-626.

Ponnamperuma, F. N. (1972). The chemistry of submerged soils. Advanced Agronomy, 24, 29-96.

Roy, M. A. (1988). Use of fatty acids for the identification of phytopathogenic bacteria. Plant Disease, 72, 460.

Sambrook, J., Fritsch, E. F., \& Maniatis, T. (1989). Molecular cloning: a laboratory manual (2nd ed.). Cold Spring Harbor, NY, USA: Cold Spring Harbor Laboratory Press.

Sequeira, L., \& Rowe, P. R. (1969). Selection and utilization of Solanum phureja clones with high resistance to different strains of Pseudomonas solanacearum. American Potato Journal, 46, 451-462.

Stover, R. H. (1979). Flooding of soil for disease control. In Mulder D. (Ed.), Soil disinfestation (pp. 19-28). Amsterdam, the Netherlands: Elsevier.

Strandberg, J. O. (1987). The effect of flooding on plant pathogen populations. In Agricultural flooding of organic soils. Bulletin 870 agricultural experiment station (pp. 41-56). University of Florida, Gainesville: Institute for Food and Agricultural Science. .

Termorshuizen, A. J., Volker, D., Blok, W. J., ten Brummeler, E., Hartog, B. J., Janse, J. D., Knol, W., \& Wenneker, M. (2003). Survival of human and plant pathogens during anaerobic mesophilic digestion of vegetable, fruit, and garden waste. European Journal of Soil Biology, 39, 165-171.

Vainio, E. J., \& Hantula, J. (2000). Direct analysis of wood-inhabiting fungi using denaturing gradient gel electrophoresis of amplified ribosomal DNA. Мyсоlogical Research, 104, 927-936.

van Diepeningen, A. D., de Vos, O. J., Korthals, G. W., \& van Bruggen, A. H. C. (2006). Effects of organic versus conventional management on chemical and biological parameters in agricultural soils. Applied Soil Ecology, 31, 120-135.

Zimnoch-Guzowska, E., Lebecka, R., \& Flis, B. (2005). Breeding for resistance to bacterial disease in potato. In E. Ritter \& A. Carrascal (Eds.), Proceedings 16th triennial conference of the European association for potato research, 17-22 July 2005 (pp. 656-659). Bilbao, Spain. 